\title{
Does Ownership Structure Matter for Bank Performance in the MENA Region? An Empirical Evidence
}

\author{
Sara Fathi (Corresponding author) \\ Assistant Lecturer of Finance, Department of Accounting and Finance \\ German University in Cairo, Egypt \\ PO Box 11835, New Cairo, Egypt \\ Tel: 20-27-589-990Ｅ-mail: sara.fathi@guc.edu.eg
}

Mona A. El Bannan

Assistant Professor of Finance, Department of Accounting and Finance

German University in Cairo, Egypt

PO Box 11835, New Cairo, Egypt

Tel: 20-27-589-990Ｅ-mail: mona.elbannan@guc.edu.eg

Received: Sep. 21, 2017 Accepted: Oct. 29, $2017 \quad$ Published: December 1, 2017

doi:10.5296/ajfa.v9i2.11942 URL: https://doi.org/10.5296/ajfa.v9i2.11942

\begin{abstract}
The aim of this study is to examine the effect of bank ownership structure on bank performance in Middle East and North Africa (MENA) region using the balanced scorecard (BSC) method. Usinga panel data of 137 commercial banks during the period from 2010 to 2014 across twelve countries in the MENA region, the study highlights the effect of ownership type and concentration on bank performance using the balanced scorecard as a performance measurement technique. The results show that government ownership and foreign ownership have statistically significant positive effect on bank performance measured by BSC index. On the contrary, domestic private ownership and ownership concentration have statistically significant negative effect on bank's BSC index. Additional analysis on each


of the BSC perspective separately reveals that ownership concentration is negatively correlated with the customer and learning and growth factors, while positively correlated with the internal process factor. Government ownership shows statistically significant negative effect on the financial factor and the internal process factor while associated with statistically significant positive effect on the customer factor. Foreign ownership has statistically significant positive effect on the financial and the internal process factor but does not have statistically significant effect on the other two perspectives. Finally, Domestic private ownership reveals a statistically significant negative effect on the learning and growth factor.

Keywords: ownership concentration, government ownership, foreign ownership, domestic private ownership, balanced scorecard, bank performance. 


\section{Introduction}

Bank ownership structure has become an important topic for many researchers and economists. While some researchers support the existence of foreign ownership in the banking sectors, others are concerned with the new challenges escalated by foreign banks entry. Foreign banks help host countries to engage in the international business cycle which stimulate the economy and lower the amplification effect of domestic shocks (Goldberg 2007; Clarke et al., 2003). Foreign banks entry is claimed to increases the efficiency of the local banking system by introducing better regulations and modern techniques of management and operations (Boussaada and Karmani, 2015; Peek and Rosengren, 2000). Nonetheless, economists debate that the entrance of these banks represents a threat for the host economy. Foreign ownership in the banking sector gives the chance to the developed countries to interfere in the host country economy and bank's regulations. Consequently, host countries lose the control over foreign banks' operations (Levine, 1996; Dermine, 2002; Barth et al., 2004; Cetorelli and Goldberg, 2009; Clarke et al., 2003).

This study is motivated by the recent restructuring process that takes place in the MENA region. Banks merger and acquisition, privatization and foreign banks entry have directed the economists and policy makers' attention to the effect of the ownership structure change on bank performance. Accordingly, the study aims to empirically investigate the effect of ownership type and concentration on bank performance using the balanced scorecard method. After the success of the balanced scorecard application on a corporate level, practitioners start to apply the balanced scorecard technique in banks and financial institutions to spot the light on the non-financial perspectives as well. Further, additional regression analysis is conducted to ensure the validity of the results and serve as a robustness check by reexamining the impact of the ownership structure on each of the four perspectives of the BSC separately.

This study contributes to the debate on the relation between ownership structure and bank performance in several important ways. It provides empirical evidence from a cross-country, emerging markets perspective, in which restructuring events affect the national economy significantly. Examining this relationship in MENA region is of much interest, as the banking industries in MENA countries have experienced many restructuring activities over the past decade. Furthermore, while most of the literature on the relationship between ownership structure and the financial performance of banks uses financial measures, only scant studies have paid little attention to the non-financial performance. To the best of my knowledge, the few studies and researches that focus on the balanced scorecard in the banking sector represent case studies considering only one or small sample of banks. Accordingly, this is the first study to employ the Balanced Scorecard (BSC) approach in examining the relationship between the ownership structure and bank performance using panel data of commercial banks in the MENA region.

\section{Literature Review and Hypothesis Development}

\subsection{Balanced Scorecard definition and its implementation in the banking sector}

The concept of "Balanced Scorecard" was first introduced by Robert Kaplan and David 
Norton in 1992. The balanced scorecard can be defined as performance measurement method that incorporates the traditional financial measures with operational measures on customer satisfaction, internal business process and organization's innovation and growth (Kaplan and Norton, 1992). Despite the fact that some versions incorporate more stakeholders and perspectives such as the environmental perspective, the basic frame of the Balanced Scorecard consists of four perspectives; Customer perspective, internal process perspective, learning and growth perspective and the financial perspective (Kaplan and Norton, 1997).

The learning and growth perspective focuses on the organizations ability to innovate, improve, grow and learn in order to accomplish their strategic objectives (Atkinson, 2006; Kaplan and Norton, 1992).The internal process perspective helps determining the crucial business processes, competencies and technologies that the organization should excel at in order to achieve the organizational objectives and meet customers' expectations. Accordingly, the internal business supports the customer perspective and the financial perspective .The customer perspective looks at the organization's ability to deliver high quality of goods and services to customers in order to maintain their satisfaction and retention. The financial perspective highlights the shareholders' interests and satisfaction through focusing on the financial success of the organization. Financial measures reveal the effect of other three perspectives of the balanced scorecard due to the causal relationship between the four perspectives (Atkinson, 2006; Kaplan and Norton, 1992; Vagizova and Klass, 2014; Isoraite, 2007).

After the success achieved through balanced scorecard implementation in corporate level, scholars and practitioners start to focus on the balanced scorecard application in the banking sector. Al-Mawali, Zainuddin and Ali (2010) study the effect of balanced scorecard on bank performance in the Jordanian banking sector. Using a sample of 120 branches, the results reveal that there is statistically significant positive relationship between BSC application and the financial performance of the branch. Ombuna et al., (2012) examine the impact of the BSC application on commercial banks performance in Kenya. Through conducting surveys on 72 department managers from 18 commercial banks, the results show that around $51.8 \%$ of the respondents strongly agree that $\mathrm{BSC}$ is a strategic management system and $57.1 \%$ strongly agree that BSC translates the organization's mission to actionable goals. Ibrahim and Murtala (2015)conduct surveys on bank executives using a sample of 11 banks in Nigeria. The study concludes that banks' executives recognize the usefulness and importance of the BSC in improving the bank performance.

\subsection{The relationship between ownership concentration and bank performance}

Many theories examine the effect of ownership concentration on bank performance. Recent researches and literature spot the light on the monitoring hypothesis, the expropriation hypothesis and neutrality hypothesis which are three contradictory hypotheses explaining the relationship between ownership concentration and bank performance. The monitoring hypothesis supports the positive relationship between ownership concentration and corporate performance. It states that concentrated ownership helps resolving the free riding problem raised by ownership dispersion as large shareholders are highly motivated to collect 
information, monitor bank's operating strategies, lending behavior and risk management which results in better governance structure (Jensen and Meckling, 1976; Shleifer and Vishny, 1986).

In contrary with the monitoring hypothesis, the Expropriation hypothesis indicates that there is a negative association between the concentration of ownership and bank performance. The inverse relation rises when large shareholders collude with managers to expropriate minority shareholders and depositors. The expropriation hypothesis claims that ownership concentration increases the agency costs and causes tunneling problem (Gutiérrez \& Tribo, 2004; Boyd et al., 1998).

The third hypothesis is the Neutrality hypothesis which is first introduced by Demsetz (1983). It indicates that there is no relationship between concentrated ownership and corporate performance claiming that the ownership structure is an endogenous variable that depends on the owners' professional knowledge, the operations scale and the technology required for business. Accordingly, there is no uniform structure of ownership is optimal for all conditions. Zouari and Taktak (2014) support the neutrality hypothesis and show that there is no relation between ownership concentration and the financial performance of Islamic banks measured by ROA and ROE. On the corporate level, using a sample of firms listed on the Shanghai and Shenzhen stock markets over the period 1997-1999, Hovey, Li and Naughton (2003) conclude that ownership concentration is irrelevant to firm performance measured by Tobin's Q.

Referring to the studies conducted in the MENA region, Aymen (2014)confirms the expropriation hypothesis using a sample of 19 banks over the period from 2000-2010 in Tunisia. The study shows that there is a negative relationship between ownership concentration and bank performance measured by ROA. The same negative association between concentrated ownership and bank performance is reported by Arouri, Hossain and Muttakin (2011) using the data of 27 banks from all the GCC countries except Kuwait for the year 2008. On the contrary, Al-Amarneh (2014) supports the monitoring hypothesis. Using a panel data for thirteen listed banks in Jordan during the period from 2000 to 2012, the results show that ownership concentration is statistically positively correlated with the ROA ratio. The same positive association is supported by Boussaada and Karmani (2015) who investigate the effect of ownership concentration on banks performance in the MENA region using a sample covering 38 commercial banks during the period from 2004 to 2011.

Since the effect of ownership concentration is still debatable and unclear, following the stream of the researches and studies stating a positive correlation between bank performance and ownership concentration, the first hypothesis to be tested in this study is:

H1: There is a significant positive relationship between ownership concentration and bank performance 


\subsection{The relationship between Ownership Type and Bank Performance}

\subsubsection{Government Ownership}

The social welfare theory and the political theory are two of the important theories explaining the behavior of state owned organizations. The social welfare theory indicates that state owned banks are social welfare- maximizing organizations that focus on economic and social growth. Pursing economic development might force public banks to engage in less profitable and riskier activities in order to motivate the business cycle and resolve financial market failures (Sapienza, 2002; Boussaada and Karmani, 2015). On the other side, the political theory claims that governmental institutions are created to serve political goals. According to this view, state owned banks serve the personal interests of politicians and act as capital suppliers for the favored political parties (Shleifer and Vishny, 1994; Shleifer, 1998).

The poor performance of state owned banks is heavily supported by many studies and articles. Kobeissi and Sun (2010) examine the effect of bank ownership structure on bank performance using panel data of 221 banks from 17 countries for the period 2000-2007. They find that government ownership has a significant negative effect on bank performance measured by ROA, ROE and profit X-efficiency. The same results are reported by Boussaada and Karmani (2015) using a sample of 38 commercial banks from the MENA region during the period from 2004-2011 and Farazi, Feyen and Rocha (2011) using a sample of 106 banks in nine non-GCC MENA countries for the period 2001-2008. The researchers refer the negative association between government ownership and bank performance to the reason that governmental banks finance public and political enterprises which raise the nonperforming loan ratios, deteriorate the loans portfolio and induce the performance measures of these banks.

In conflict with the social welfare and the political theory, Loukil and Chaabane (2005) report a positive relationship between government ownership and bank performance in Tunisia. They refer the good performance of public banks to the social benefits they receive in comparison with their private counterparts. Sathye (2003) study the effect of ownership structure on bank productive efficiency in India during the period from 1997 to 1998 . Using Data Envelopment Analysis (DEA), the results indicate that state owned banks outperform privately owned banks particularly during the expansionary phase when the fixed costs of privately owned banks are high. As the previous researches report conflicted results with respect to the effect of government ownership on bank performance and based on the majority of the studies and researches covering this relationship, the second hypothesis to be examined in this study is:

\section{$\mathrm{H}_{2}$ : There is a significant negative relationship between government ownership and bank performance.}

\subsubsection{Foreign Versus Domestic Ownership}

The effect of foreign ownership on bank performance is still an area of argument between researchers and practitioners. In this respect, Berger et al., (2000) compare between the performance of foreign banks and the domestic ones. He argues that two core contradictory 
hypotheses reveal the relationship between foreign ownership and bank performance: home field advantage hypothesis versus global advantage hypothesis. Home Field advantage may partially appear because of the organizational diseconomies and the high operations and monitoring costs of working abroad. Foreign institutions may lack local information about the new market which escalates difficulties in maintaining deposit relationships with domestic clients or lending relationships with small and mid-size enterprises. Consequently, domestic banks have privileges over foreign ones making the latter less efficient and profitable (Berger et al., 2000).

On the other side, Global advantage hypothesis indicates that efficiently managed foreign institutions can resolve the problems of operating in a distant market. Foreign institutions may have better operating strategies, more advanced techniques and superior diversification and risk management skills. Accordingly, foreign institutions can offer better financial access for households and improve the quality of the service offered to customers (Berger et al., 2000; Akhtar, 2010).

Using a sample of commercial banks in Pakistan for the period from 2001 to 2006,Akhtar (2010) examines the effect of the ownership structure on bank efficiency applying Data Envelopment Analysis (DEA). the results supports the global advantage theory that foreign banks are able to overcome the challenges of operating in new market through their superior management techniques, well diversified investment portfolio and better services. The positive relationship between foreign ownership and bank performance is confirmed by many studies and researches that focus on the MENA region (Al-Amarneh, 2014; Boussaada and Karmani, 2015; Arouri, Hossain and Muttakin, 2011). On the contrary,Lensink and I. Naaborg (2007) support the home field advantage. Employing the system generalized methods of moments (GMM) technique on a panel data of banks worldwide, they report negative relationship between foreign ownership and banks' interest revenues and profitability. The researchers refer to the home field advantage as a main reason justifying the findings.

Based on the above mentioned arguments, the following hypotheses are developed;

\section{$\mathrm{H}_{3}$ : there is a significant positive relationship between foreign ownership and bank performance.}

$\mathrm{H}_{4}$ : there is a significant positive relationship between domestic private ownership and bank performance.

\section{Research Methodology}

\subsection{Sample and Data}

The sample of this study includes 137 commercial banks during the period from 2010 to 2014 across twelve countries in the MENA region: Egypt, Algeria, Bahrain, Jordan, Kuwait, Morocco, Oman, Qatar, Saudi Arabia Tunisia, United Arab Emirates and Yemen. Other countries like Iraq, Syria, Libya, Lebanon, Palestinian Territory and Israel are excluded due to the wars and political instability. From other side, Iran is excluded from the sample as it 


\section{Al Macrothink}

Asian Journal of Finance \& Accounting

ISSN 1946-052X

2017, Vol. 9, No. 2

follows Islamic economy and it has only 1 commercial bank started to operate in 2012. This study excludes Islamic banks as they have different objectives and strategies. Accordingly, the balanced scorecard for Islamic banks should include different measures to convey their missions and goals.

The 137 banks considered in this study for 5 years from the year 2010 till 2014 resulted in 685 bank-year observations. Table (1) shows the final sample after dropping the missing data since some banks start to operate after the year 2010 and other banks are merged or acquired by other banks during the sample period, it ends up with 637 bank-year observations.

Table 1. Sample by Country

\begin{tabular}{llll}
\hline Country & Target Population & Sample Size & Percentage \\
Egypt & 23 & 23 & $17 \%$ \\
Yemen & 5 & 4 & $3 \%$ \\
Oman & 6 & 6 & $4 \%$ \\
Kuwait & 6 & 5 & $4 \%$ \\
UAE & 20 & 18 & $13 \%$ \\
Bahrain & 12 & 10 & $7 \%$ \\
Qatar & 7 & 7 & $5 \%$ \\
Tunisia & 17 & 16 & $12 \%$ \\
Jordan & 10 & 10 & $7 \%$ \\
Morocco & 14 & 13 & $9 \%$ \\
Algeria & 17 & 17 & $12 \%$ \\
Saudi Arabia & 8 & 8 & $6 \%$ \\
Total & 145 & 137 & $100 \%$ \\
\hline
\end{tabular}

Notes: Distribution of the sample by country

With respect to the data collection, all the bank-level accounting information and financial ratios are mainly obtained from the Bank Scope database and in case of a missing data and sometimes for the reason of double check, the balance sheet and income statements are retrieved from the bank website. Other data like the number of employees, number of branches and the ownership data are obtained from the banks' annual reports and websites. The inflation rate and GDP growth rate obtained from the World Bank database and the annual reports of the central bank in each country.

\subsection{Econometric Models}

In order to test the study hypotheses, four pooled OLS regression models are constructed to estimate the relationships of the study and test each hypothesis. Each regression model is used to test all four hypotheses, while relying on two alternative measures for ownership concentration and liquidity to ensure robustness of results. In other words, the main 
relationships are re-estimated using different measures to assure that results obtained are not violated.

\section{Model 1}

$\mathrm{BSC}$ Index $=\alpha+\beta 1$ FOR $\%+\beta 2$ GOV $\%+\beta 3 D_{-} P R V \%+\beta 4$ CON1 $+\beta 5$ Size $+\beta 6$ LIQ1+

$$
\beta 7 C A P A D Q+\beta 8 G D P+\beta 9 I N F+\beta 10 \text { Year }+\varepsilon
$$

\section{Model 2}

$$
\begin{gathered}
\mathrm{BSC} \text { Index }=\alpha+\beta 1 \text { FOR } \%+\beta 2 \text { GOV } \%+\beta 3 D_{-} P R V \%+\beta 4 \text { MAJSH }+\beta 5 \text { Size }+\beta 6 \\
L I Q 1+\beta 7 C A P A D Q+\beta 8 G D P+\beta 9 I N F+\beta 10 \text { Year }+\varepsilon
\end{gathered}
$$

\section{Model 3}

$$
\begin{gathered}
\mathrm{BSC} \text { Index }=\alpha+\beta 1 F O R \%+\beta 2 G O V \%+\beta 3 D_{-} P R V \%+\beta 4 C O N 1+\beta 5 \text { Size }+\beta 6 \text { LIQ2+ } \\
\beta 7 C A P A D Q+\beta 8 G D P+\beta 9 \text { INF }+\beta 10 \text { Year }+\varepsilon
\end{gathered}
$$

\section{Model 4}

BSC Index $=\alpha+\beta 1 F O R \%+\beta 2 G O V \%+\beta 3 D_{-} P R V+\beta 4$ MAJSH $+\beta 5$ Size $+\beta 6$ LIQ2 +

$$
\beta 7 C A P A D Q+\beta 8 G D P+\beta 9 I N F+\beta 10 \text { Year }+\varepsilon
$$

\subsection{Variables Definition}

To measure the bank performance as a dependent variable using balance scorecard composite index, different variables are used to represent each of the four perspectives of the balanced scorecard. Consistent with the previous studies (Al-Najjar and Kalaf, 2012; Elbannan and Elbannan, 2014; Tominac, 2014), return on equity (ROE), return on assets (ROA) and net interest margin (NIM) are used as indicators for the financial performance of the bank.

Following the study conducted by Laeven and Levine (2009). The customer perspective is measured using Bank's deposit market share (DMKTSH,). The DMKTSH is used as a proxy for the customer retention and satisfaction. For the internal business perspective, credit growth and deposits growth (Current, Saving, and term) are used as an indicator of the growth of the banking services. The cost to income ratio (CTI) is used as efficiency indicator. It reflects the management ability to control its costs and raise high income relative to the total costs (Rose and Hudgins, 2008). To reflect the asset quality, the nonperforming loan ratio (NPL) is employed. Many scholars argue that asset quality measured by the ratio of nonperforming loans to total loans have significant negative impact on bank efficiency. High NPL ratio reveals inadequate credit policy and poor evaluation and monitoring process (Karim et al., 2010; Hughes and Mester, 1993; Altunbas et al., 2000; Girardone et al., 2004).

The fourth and final perspective in the BSC is the leaning and growth. Following Wang (2005), employee productivity (E. Prod) and Branch productivity (B. Prod) are used as proxies for bank learning and growth.

Regarding the explanatory variables, The ownership type is classified into 3 types: Foreign ownership, government ownership and domestic private ownership. Each one of them is measured as a percentage. Ownership concentration is measured by two mutually used 
variables: CON1 is the percentage of equity held by the largest shareholder and MAJSH is the percentage of equity held by major shareholders who owe $5 \%$ or more. Other factors that may affect bank performance are taken into consideration as control variables like capital adequacy, liquidity, bank size, GDP growth and inflation rate. Capital adequacy is expected to have positive effect on bank performance as banks with good capital adequacy ratio are less exposed to bankruptcy problems which decreases the fund raising costs and results in better bank performance (Berger et al., 1995; Goddard et al., 2004). Bank size is expected to have positive effect on bank performance assuming increasing return to scale. Bank size in terms of total assets is found to have a direct effect on bank profitability especially on the return on assets ratio (ROA) (Panayiotis et al., 2005; Sudin, 1996; Valentina et al., 2009; Arif et al., 2013).

From other side, liquidity is expected to have a negative effect on bank performance. Assuming competitive deposits market, high liquidity ratios result in low net interest margin which inversely affects the bank performance. Two liquidity indicators are used in this study, the ratio of liquid assets to total deposits and short term funding shows what percentage of a bank's deposits and short term finding is held in liquid form. The second indicator for the bank liquidity is liquid asset to total deposit and borrowing which relates liquid assets to the deposits and borrowing levels (Naceur and Kandil, 2009).

Macroeconomic factors like the real GPD growth and the inflation rate (INF) are taken into consideration. During the period of economic boom and high real GDP, banks are expected to report high performance measures and vice versa during economic recession. From other side, prior studies do not report a clear relationship between the bank performance and the inflation rate. Based on the economic conditions in the MENA region, inflation is expected to have a negative effect on banks' performance as inflation decreases the real income for households which lead to a fall in the total demand on goods and services. Consequently, organizations reduce their production and cut their investments and borrowing plans especially for variable-rate loans (Athanasoglou et al., 2008; Perry, 1992; Boyd et al., 2001; Umer et al., 2014).

Table 2. Variables definition

\begin{tabular}{|c|c|c|c|}
\hline \multicolumn{4}{|l|}{ Dependent Variables } \\
\hline Variable & & Measurement & Source \\
\hline $\begin{array}{l}\text { Return on average } \\
\text { Assets }\end{array}$ & $R O A A$ & net income/ average total assets, $\%$ & $\begin{array}{l}\text { Bankscope/Financial } \\
\text { Statements }\end{array}$ \\
\hline $\begin{array}{l}\text { Return on average } \\
\text { Equity }\end{array}$ & $R O A E$ & net income/ average total Equity, $\%$ & $\begin{array}{l}\text { Bankscope/Financial } \\
\text { Statements }\end{array}$ \\
\hline $\begin{array}{l}\text { Return on average } \\
\text { Equity }\end{array}$ & $R O A E$ & net income/ average total Equity, $\%$ & $\begin{array}{l}\text { Bankscope/Financial } \\
\text { Statements }\end{array}$ \\
\hline Net Interest Margin & NIM & Net interest revenue/ Total earning assets & $\begin{array}{l}\text { Bankscope/Financial } \\
\text { Statements }\end{array}$ \\
\hline Credit growth & $C r$ & Percentage Change in total loans & Bankscope/Financial \\
\hline
\end{tabular}




\begin{tabular}{|c|c|c|c|c|}
\hline \multicolumn{4}{|c|}{ Growth } & \multirow{2}{*}{$\begin{array}{l}\text { Statements } \\
\text { Bankscope/Financial } \\
\text { Statements }\end{array}$} \\
\hline $\begin{array}{l}\text { Deposit } \\
\text { share }\end{array}$ & Market & $D M S H$ & $\begin{array}{l}\text { Bank deposits divided by total deposits of all } \\
\text { banks }\end{array}$ & \\
\hline $\begin{array}{l}\text { Current } \\
\text { Growth }\end{array}$ & Deposits & $C D G$ & Percentage Change in Current Accounts & $\begin{array}{l}\text { Bankscope/Financial } \\
\text { Statements }\end{array}$ \\
\hline $\begin{array}{l}\text { Saving } \\
\text { Growth }\end{array}$ & Deposits & $S D G$ & Percentage Change in Saving Accounts & $\begin{array}{l}\text { Bankscope/Financial } \\
\text { Statements }\end{array}$ \\
\hline $\begin{array}{l}\text { Term } \\
\text { Growth }\end{array}$ & Deposit & $T D G$ & Percentage Change in Term Accounts & $\begin{array}{l}\text { Bankscope/Financial } \\
\text { Statements }\end{array}$ \\
\hline $\begin{array}{l}\text { Non-perfo } \\
\text { loan rate }\end{array}$ & rming & $N P L$ & Impaired loans/ Gross loans & $\begin{array}{l}\text { Bankscope/Financial } \\
\text { Statements }\end{array}$ \\
\hline Cost to inc & come ratio & $C I R$ & $\begin{array}{l}\text { Overhead Costs/ (Other Operating } \\
\text { Income+Net interest Rvenue) }\end{array}$ & $\begin{array}{l}\text { Bankscope/Financial } \\
\text { Statements }\end{array}$ \\
\hline $\begin{array}{l}\text { Employee } \\
\text { productivi }\end{array}$ & & E.Prod & $\begin{array}{l}\text { Log of ( Operating income/ no. of } \\
\text { employees) }\end{array}$ & $\begin{array}{l}\text { Bankscope/Financial } \\
\text { Statements }\end{array}$ \\
\hline Branch pro & oductivity & B.Prod & Log of ( Operating income/ no. of branches) & $\begin{array}{l}\text { Bankscope/Financial } \\
\text { Statements }\end{array}$ \\
\hline $\begin{array}{l}\text { Learning } \\
\text { index }\end{array}$ & composite & Learn F. & $\begin{array}{l}\text { Leanin score generated by factor analysis of } \\
\text { bank i's in year t. }\end{array}$ & $\begin{array}{l}\text { Factor Analysis } \\
\text { Author constructed }\end{array}$ \\
\hline $\begin{array}{l}\text { Financial } \\
\text { index }\end{array}$ & composite & FIN. F & $\begin{array}{l}\text { Financial score generated by factor analysis } \\
\text { of bank i's in year t }\end{array}$ & $\begin{array}{l}\text { Factor Analysis } \\
\text { Author constructed }\end{array}$ \\
\hline $\begin{array}{l}\text { Internal } \\
\text { composite }\end{array}$ & $\begin{array}{l}\text { business } \\
\text { index }\end{array}$ & INPro.F & $\begin{array}{l}\text { Internal business score generated by factor } \\
\text { analysis of bank i's in year } \mathrm{t}\end{array}$ & $\begin{array}{l}\text { Factor Analysis } \\
\text { Authorconstructed }\end{array}$ \\
\hline $\begin{array}{l}\text { Customer } \\
\text { index }\end{array}$ & composite & Cust.F & $\begin{array}{l}\text { Customer score generated by factor analysis } \\
\text { of bank i's in year } t\end{array}$ & $\begin{array}{l}\text { Factor Analysis } \\
\text { Authorconstructed }\end{array}$ \\
\hline $\begin{array}{l}\text { BSC } \\
\text { Index. }\end{array}$ & Composite & $\begin{array}{l}B S C \\
\text { Index }\end{array}$ & $\begin{array}{l}\text { Bank performance score measured as a } \\
\text { multidimensional composite index generated } \\
\text { by factor analysis of banks I's score in year } \mathrm{t} \\
\text { on each of the following indicators: Factor } 1 \\
\text { leaning, Factor } 2 \text { financial, factor } 3 \text { internal } \\
\text { business and factor } 4 \text { customer. }\end{array}$ & $\begin{array}{l}\text { Factor Analysis } \\
\text { Author constructed }\end{array}$ \\
\hline
\end{tabular}

\section{Explanatory variables}

Foreign ownership FOR \% percentage

Governmental $\quad G O V \%$
ownership

percentage
Percentage of shares held by the foreign investors

$$
\begin{aligned}
& \text { Percentage of shares held by the } \\
& \text { government }
\end{aligned}
$$

Annual

reports/ bank

website

\section{Statements}

ankscope/Financial

Bankscope/Financial

Bankscope/Financial

Statements

Statements

Statements

Financial

(n)

(n)




\begin{tabular}{|c|c|c|c|c|c|}
\hline $\begin{array}{l}\text { Domestic private } \\
\text { ownership } \\
\text { percentage }\end{array}$ & $D_{-} P R V \%$ & $\begin{array}{l}\text { Percentage of shares held by domestic private } \\
\text { institutions or individuals }\end{array}$ & $\begin{array}{l}\text { Annual } \\
\text { website }\end{array}$ & reports/ & bank \\
\hline Major shareholders & MAJSH & $\begin{array}{l}\text { Adding up all shareholding owning } 5 \% \text { or } \\
\text { more }\end{array}$ & $\begin{array}{l}\text { Annual } \\
\text { website }\end{array}$ & reports/ & bank \\
\hline Largest shareholder & CON1 & $\begin{array}{l}\text { the shareholder owning the highest } \\
\text { percentage of shares }\end{array}$ & $\begin{array}{l}\text { Annual } \\
\text { website }\end{array}$ & reports/ & bank \\
\hline
\end{tabular}

\begin{tabular}{|c|c|c|c|}
\hline \multicolumn{4}{|l|}{ Control variables } \\
\hline $\begin{array}{l}\text { Liquid Assets to } \\
\text { total deposits and } \\
\text { Short Term funding }\end{array}$ & LIQ 1 & $\begin{array}{l}\text { Liquid Assets divided by total deposits and } \\
\text { Short Term funding }\end{array}$ & $\begin{array}{l}\text { Bankscope /Financial } \\
\text { Statements }\end{array}$ \\
\hline $\begin{array}{l}\text { Liquid Assets to } \\
\text { total deposits and } \\
\text { borrowing }\end{array}$ & LIQ 2 & $\begin{array}{l}\text { Liquid Assets divided by total deposits and } \\
\text { borrowing }\end{array}$ & $\begin{array}{l}\text { Bankscope/Financial } \\
\text { Statements }\end{array}$ \\
\hline $\begin{array}{l}\text { Equity to Total } \\
\text { Assets }\end{array}$ & $C A P A D Q$ & Book value of Equity to total assets & $\begin{array}{l}\text { Bankscope/Financial } \\
\text { Statements }\end{array}$ \\
\hline Bank Size & Size & Natural logarithm of total assets & $\begin{array}{l}\text { Bankscope/Financial } \\
\text { Statements }\end{array}$ \\
\hline Real GDP Growth & $G D P$ & Official Annual GDP growth figures & $\begin{array}{l}\text { World development } \\
\text { indicators of the World }\end{array}$ \\
\hline & & & $\begin{array}{l}\text { Bank/ Central banks } \\
\text { reports }\end{array}$ \\
\hline Inflation Rate & $I N F$ & Official Annual inflation rate & $\begin{array}{l}\text { World development } \\
\text { indicators of the World } \\
\text { Bank/ Central banks } \\
\text { reports }\end{array}$ \\
\hline Time effect & YearCode & $\begin{array}{l}\text { Categorical variable representing code of } \\
\text { year } t\end{array}$ & Author-constructed \\
\hline
\end{tabular}

Notes: Variables definition and data source

\section{Empirical results}

\subsection{Descriptive analysis}

The descriptive statistics for the entire set of included variables are reported in Table 3. The table presents the descriptive statistics for the various bank characteristics variables, in addition to those for the macroeconomic variables. 
Table 3. Descriptive Statistics

\begin{tabular}{llllllll}
\hline Variables & Mean & Median & Std. Dev & Skewness & Kurtosis & Min. & Max. \\
\hline ROAA & 1.333 & 1.558 & 3.420 & -12.172 & 184.828 & -55.487 & 7.393 \\
ROAE & 10.867 & 12.024 & 20.793 & -7.897 & 173.478 & -357.108 & 218.009 \\
NIM & 3.650 & 3.282 & 1.903 & 1.368 & 4.376 & -3.445 & 12.204 \\
DMSH & 0.096 & 0.053 & 0.120 & 2.327 & 6.527 & 0.000 & 0.782 \\
CDG & 0.260 & 0.130 & 0.840 & 8.009 & 81.785 & -1.000 & 11.000 \\
SDG & 0.170 & 0.100 & 0.588 & 7.883 & 86.495 & -1.000 & 8.000 \\
TDG & 0.240 & 0.040 & 2.480 & 18.147 & 363.059 & -1.000 & 51.000 \\
Cr.Growth & 15.964 & 8.930 & 55.766 & 10.992 & 140.570 & -99.740 & 789.270 \\
NPL & 8.124 & 5.004 & 9.382 & 3.146 & 12.548 & 0.053 & 65.936 \\
CIR & 45.430 & 42.050 & 23.534 & 5.086 & 47.315 & 9.000 & 333.000 \\
E. Prod. & 2.256 & 2.234 & 0.387 & 0.702 & 1.788 & 1.227 & 3.921 \\
B. Prod. & 3.652 & 3.595 & 0.546 & -2.013 & 13.713 & -0.609 & 4.632 \\
CAPADQ & 14.175 & 12.341 & 10.229 & -0.794 & 26.979 & -95.936 & 66.830 \\
Size & 6.664 & 6.629 & 0.670 & -0.133 & -0.369 & 4.504 & 8.126 \\
LIQ 1 & 35.756 & 25.628 & 28.156 & 1.719 & 3.373 & 2.011 & 186.522 \\
LIQ2 & 30.695 & 23.302 & 23.502 & 1.732 & 3.293 & 1.375 & 147.864 \\
GOV \% & 0.789 & 0.793 & 0.209 & -0.157 & -1.738 & 0.492 & 1.000 \\
FOR \% & 0.819 & 0.880 & 0.178 & -0.410 & -1.406 & 0.500 & 1.000 \\
D_PRV\% & 0.744 & 0.750 & 0.178 & 0.011 & -1.437 & 0.503 & 1.000 \\
CON 1 & 0.567 & 0.500 & 0.309 & 0.170 & -1.350 & 0.050 & 1.000 \\
MAJSH. & 0.776 & 0.845 & 0.231 & -0.957 & 0.327 & 0.010 & 1.000 \\
INF. & 4.950 & 4.200 & 3.489 & 0.652 & 0.085 & -2.400 & 19.500 \\
GDP & 3.459 & 3.000 & 2.877 & 0.767 & 15.502 & -15.100 & 19.600 \\
\hline & & & & & & & \\
\hline
\end{tabular}

Notes: The table presents the distribution of variables by showing mean, median, standard deviation, Skewness, Kurtosis, minimum and maximum. See Table 2 for variable definitions.

Table (3) shows that the average ROA for the banks included in the sample is low $1.33 \%$ while the average value of ROE is a bit higher $10.87 \%$ as a result of financial leverage. The average NIM is $3.65 \%$. The average cost to income ratio is $45.43 \%$ indicating low operating efficiency due to high operating expenses. The average ownership concentration is high for the two measures. The average shares hold by the major shareholder owning higher than $5 \%$ is $56.7 \%$ while the average shares hold by the largest 5 shareholders is $77.6 \%$. There is a high trend of foreign ownership in the banking sector in the MENA region. Foreign ownership represents on average $81.9 \%$. The average government ownership is $78.9 \%$ while the domestic private ownership is $74.4 \%$ 


\section{Sample by Country}

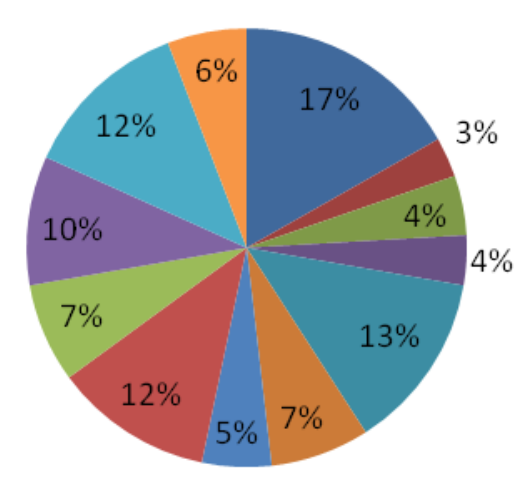

Egypt

- Yemen

Oman

- Kwait

UAE

Bahrain

- Qatar

- Tunisia

Figure 1. Distribution of the Sample

Figure 1 shows that Egypt and the United Arab Emirates represent the highest percentage of banks included in the sample $17 \%$ and $13 \%$ respectively while Yemen represents the lowest percentage; only $3 \%$ of total banks in the sample.

\subsection{Pearson Correlation Matrix}

Table 4 represents the Pearson correlation results between variables. The results reveal that foreign ownership is positively correlated with financial performance variables; ROAA, ROAE and NIM. The positive correlation between foreign ownership and ROA is significant at $10 \%$ while the positive correlation between foreign ownership and the ROE is significant at $1 \%$. Government ownership is negatively correlated with the ROA and positively correlated with the ROE and NIM however the results are not statistically significant. 
Table 4. Correlation Matrix

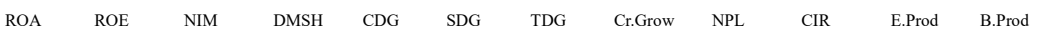

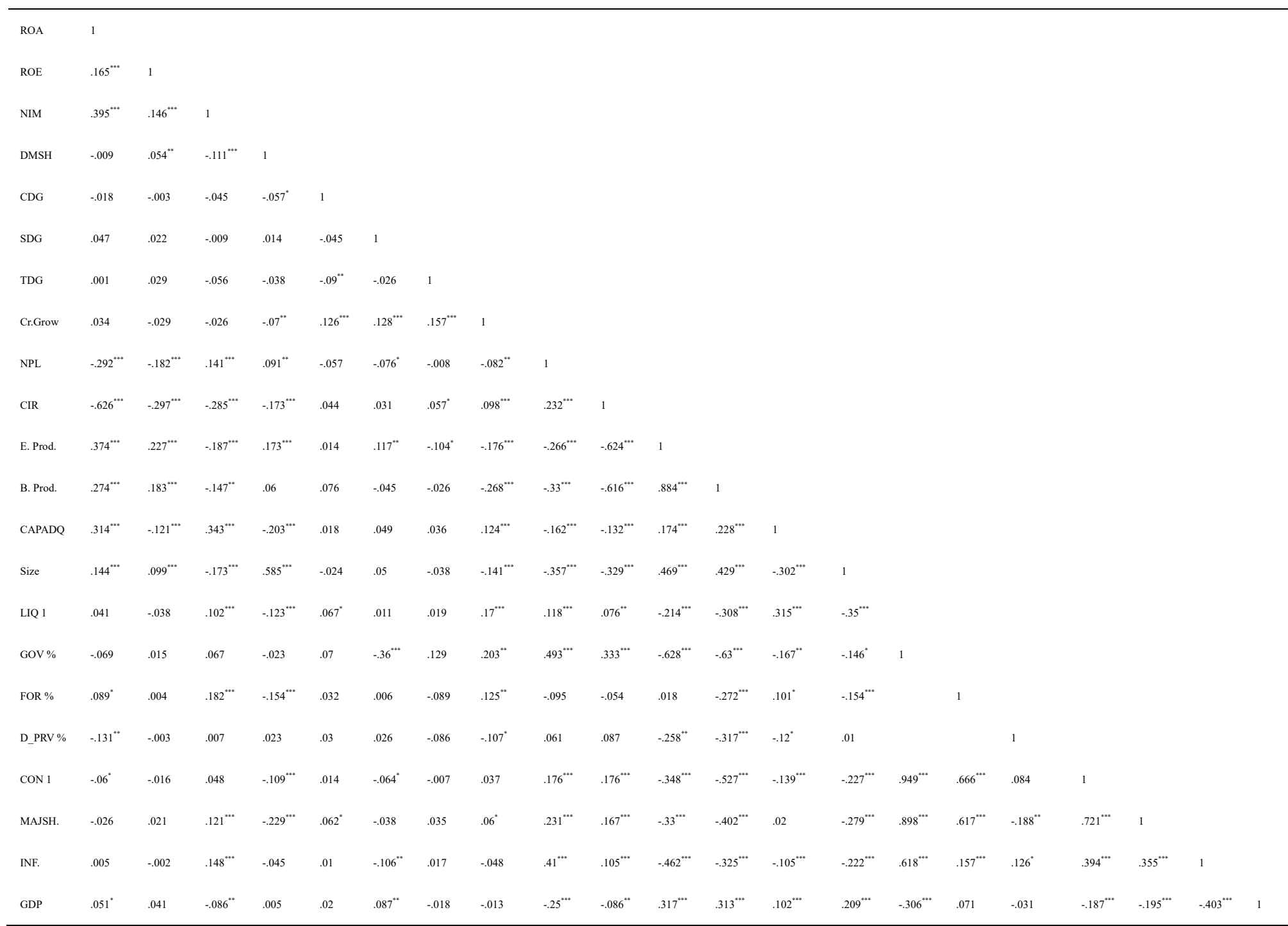

Notes: The table shows Pearson pairs-wise correlation matrix. ***,***Significant at 1,5 and 10 percent levels, respectively. Variables definition is presented in Table 2

\subsection{Principal Component Analysis}

In order to construct the four components representing the four perspectives of the balanced scorecard, principal component analysis is used as a data reduction technique for the twelve dependent variables used as indicators for the different perspectives. Afterward, the balanced scorecard index is obtained by multiplying each individual score with their respective factor loading scores and then added up all products together to get a weighted average score. 
Table 5. Rotated Component Matrix ${ }^{\mathrm{a}}$

\begin{tabular}{lllll}
\hline & \multicolumn{3}{l}{ Component } & \\
\cline { 2 - 5 } & 1 & 2 & 3 & 4 \\
\hline ROAA & .251 & .887 & -.033 & -.038 \\
ROAE & .095 & .866 & .016 & .013 \\
NIM & -.668 & .576 & -.029 & -.118 \\
DMKTSH & .200 & -.138 & -.127 & .659 \\
CDG & .000 & .106 & .788 & .275 \\
SDG & .007 & -.105 & .820 & -.040 \\
TDG & .165 & -.247 & -.234 & -.710 \\
Cr. Growth & .107 & -.086 & .856 & -.151 \\
E.Prod & .886 & .296 & .058 & .160 \\
B.Prod & .885 & .205 & -.026 & -.010 \\
CIR & -.445 & -.671 & .175 & -.204 \\
NPL & -.513 & -.264 & -.225 & .282 \\
\hline
\end{tabular}

The Rotated Component Matrix shows the factor loadings for each variable. Factor 1 is highly correlated with employee productivity and branch productivity and accordingly it represents the learning and growth perspective. Factor 2 is most highly correlated with ROAA, ROAE and NIM which represent the financial perspective. Current deposits growth, saving deposits growth and credit growth loaded strongly on factor 3 which represents the internal process perspective. Deposit market share strongly loaded on factor 4 which represent the customer perspective.

Table 6. KMO and Bartlett's Test

\begin{tabular}{|l|l|l|}
\hline Kaiser-Meyer-Olkin Measure of Sampling Adequacy. & 642 \\
\hline \multirow{3}{*}{ Bartlett's Test of Sphericity } & Approx. Chi-Square & 816.926 \\
\cline { 2 - 3 } & df & 66 \\
\cline { 2 - 3 } & Sig. & .000 \\
\hline
\end{tabular}

KMO test is a measure of sampling adequacy for factor analysis. In this study, the KMO measure is 0.642 indicating that the sampling adequacy is mediocre. Accordingly, the factors extracted will account for fair amount of variance but not a substantial amount. The conducted factor analysis is statistically significant at $1 \%$. 
Table 7. Total Variance Explained

\begin{tabular}{lllllll}
\hline & \multicolumn{3}{l}{ Initial Eigenvalues } & \multicolumn{3}{l}{ Rotation Sums of Squared Loadings } \\
\cline { 2 - 7 } 1 & 3.368 & 28.063 & 28.063 & 2.628 & 21.897 & 21.897 \\
2 & 2.241 & 18.671 & 46.734 & 2.626 & 21.886 & 43.783 \\
3 & 1.853 & 15.441 & 62.175 & 2.184 & 18.204 & 61.987 \\
4 & 1.178 & 9.817 & 71.991 & 1.201 & 10.005 & 71.991 \\
5 & .953 & 7.946 & 79.937 & & & \\
6 & .735 & 6.129 & 86.066 & & & \\
7 & .468 & 3.896 & 89.962 & & & \\
8 & .400 & 3.337 & 93.299 & & & \\
9 & .321 & 2.678 & 95.977 & & & \\
10 & .241 & 2.006 & 97.983 & & & \\
11 & .162 & 1.352 & 99.334 & & & \\
12 & .080 & .666 & 100.000 & & & \\
\end{tabular}

Notes: Extraction Method: Principal Component Analysis.

In Table 7, the total column in the initial eigenvalues shows the amount of variance in the original variables accounted for by each component. Considering the components with eigenvalues higher than one, the first four components are chosen. Factor 1 learning and growth has an eigenvalue $=3.368$ which means that this factor explains more variance than a single variable. Factor 2 financial has an eigenvalue $=2.241$ which means that total variance explained by this factor is $18.671 \%$. Factor 3 internal process has an eigenvalue $=1.853$ and explains $15.441 \%$ of the total variance. Factor 4 customer has an eigenvalue $=1.178$ and the total variance explained by this factor is $9.817 \%$. These four components account for $71.991 \%$ of the variability on the dependent variable which is the bank performance measured by the BSC Index.

4.4 Regression Analysis 


\section{Mll Macrothink}

Table 7. BSC Models

\begin{tabular}{|c|c|c|c|c|c|c|c|c|}
\hline \multirow[t]{2}{*}{ BSC index } & \multicolumn{2}{|l|}{ Model 1} & \multicolumn{2}{|c|}{ Model 2} & \multicolumn{2}{|c|}{ Model 3} & \multicolumn{2}{|c|}{ Model 4} \\
\hline & Coef. & t-statistics & Coef. & t-statistics & Coef. & t-statistics & Coef. & t-statistics \\
\hline (Constant) & -.174 & -1.094 & -.100 & -.630 & -.184 & -1.153 & -.111 & -.696 \\
\hline GOV\% & -.011 & -.107 & .038 & .357 & .019 & .174 & .061 & $.566^{* *}$ \\
\hline FOR \% & .130 & $1.670^{* *}$ & .135 & $1.817^{* *}$ & .141 & $1.821^{*}$ & .145 & $1.950^{* * *}$ \\
\hline D_PRV\% & -.372 & $-3.994^{* * *}$ & -.420 & $-4.465^{* * *}$ & -.361 & $-3.878^{* * *}$ & -.405 & $-4.311^{* * *}$ \\
\hline CON1 & -.064 & $-1.883^{* *}$ & & & -.061 & $-1.802^{*}$ & & \\
\hline MAJSH & & & -.146 & $-3.178^{* * *}$ & & & -.134 & -2.939 \\
\hline CAPADQ & .000 & .433 & .001 & .609 & .001 & .793 & .001 & .973 \\
\hline Size & .058 & $3.994^{* * *}$ & .056 & $3.891^{* * *}$ & .056 & $3.874^{* * *}$ & .053 & $3.750^{* * *}$ \\
\hline LIQ1 & $6.85 \mathrm{E}-5$ & .195 & .000 & .590 & & & & \\
\hline LIQ2 & & & & & -.001 & -1.215 & .000 & -.800 \\
\hline INF & -.004 & $-1.412^{*}$ & -.003 & -1.257 & -.004 & $-1.462^{*}$ & -.004 & $-1.358^{*}$ \\
\hline GDP & .003 & .841 & .002 & .773 & .002 & .782 & .002 & .711 \\
\hline F-statistics & 5.226 & & 5.777 & & 5.348 & & 5.802 & \\
\hline $\mathrm{p}$-value for $\mathrm{F}$ - test & .000 & & .000 & & .000 & & .000 & \\
\hline R-squared & .090 & & 0.098 & & .092 & & .099 & \\
\hline Adjusted R2 & .073 & & .081 & & .075 & & .082 & \\
\hline Mean VIF & 1.3 & & 1.28 & & 1.78 & & 1.26 & \\
\hline
\end{tabular}

Notes: $* * *$ Statistically significant at $1 \%, * *$ statistically significant at $5 \%$, *statistically significant at $10 \%$.

In Table 8 , the four BSC models are highly significant with $\mathrm{p}$-value $=0.000$. The average variance inflation factor (VIF) of the model variables are below 10 indicating that there is no multicollinearity problem exists. The findings of the four models reveal that foreign ownership has a significant positive effect on overall bank performance measured by BSC index. The result is statistically significant at 5\% in model 1 and 2 , significant at $10 \%$ in model 3 and significant at $1 \%$ in model 4 . This result supports the global advantage hypothesis that an increase in foreign ownership leads to higher bank performance, better operating strategies, more advanced techniques and superior diversification and risk management skills. The result is consistent with the results of the previous studies (Al-Amarneh, 2014; Akhtar, 2010; Boussaada and Karmani, 2015; Arouri, Hossain and Muttakin, 2011).

On the other side, domestic private ownership shows a negative impact on bank performance that is statistically significant at $1 \%$ in the four models. This negative relationship between 
domestic private ownership and bank performance might be due to the high fixed costs they bear during the expansionary phase or the ineffective strategy to attract more customer deposits at low cost. The result is consistent with the result found by (Chaabane and Loukil, 2005; Sathye, 2003; Wanniarachchige, 2011).

Government ownership has no statistically significant effect in model 1, 2 and 3 while it shows positive significant effect on bank performance in model 4 . The result is statistically significant at 5\%. The positive effect of government ownership on bank performance is consistent with the previous results by Loukil and Chaabane, 2005; Sathye, 2003 and Wanniarachchige, 2011 who refer the positive relation between state ownership and bank performance to the strong support of the government and long experience in the sector. Governmental banks may enjoy superior advantage in attracting customer deposits at lower costs compared to foreign and domestic private counterparts. Another reason for the positive association between government ownership and bank performance is that governmental banks may have more credits transactions, investments and projects in different and district regions in that are not targeted by foreign and domestic private banks which help raise governmental banks performance. On the other hand, this positive relationship contradicts the social welfare theory and the political theory (Sapienza, 2002; Boussaada and Karmani, 2015; Shleifer and Vishny, 1994; Shleifer, 1998).

The regression results reveal that the two measures used for ownership concentration are associated with negative bank performance measured by BSC index. In model 1 and 3, ownership concentration measure CON1 has statistically significant negative effect on bank performance. The result is statistically significant at 5\% in model 1 and significant at $10 \%$ in model 3. In model 2, ownership concentration measure MAJSH has significant negative effect on overall bank performance. The result is statistically significant at $1 \%$. This confirm the expropriation hypothesis which states that ownership concentration has an adverse effect on bank performance as it may increase the agency costs and cause tunneling problem. The results is consistent with (Gutiérrez \&Tribo, 2004; Boyd et al., 1998; Filatotchev et al.,2001; Alimehmeti and Paletta, 2012; Pinto and Augusto,2014; Lee, 2008; Su and He,2012) and contradicts with (Jensen and Meckling, 1976; Shleifer and Vishny, 1986; Affes and Hakim, 2013; Heugens et al., 2009; Son et al.,2015) who support the positive association between ownership concentration and bank performance according to the monitoring hypothesis. Bank size has a significant positive effect on overall bank performance measured by BSC. The result is statistically significant at $1 \%$ in the four models which is consistent with Sudin (1996) and Valentina et al., (2009) due to increasing return to scale. Inflation has a negative effect on bank performance that is statistically significant at $10 \%$ in model 1,3 and 4 . The result is consistent with Boyd et al. (2001) and Umer et al., (2014).

\subsection{Additional Analysis}

Additional regression analyses are made to test the effect of ownership structure on each perspective of the balanced scorecard separately (the financial perspective, customer, internal process and learning and growth perspective). The main relationship of the study will be reexamined by using each perspective of the balanced scorecard as a dependent variable and 
re-estimate the regression models. These additional robustness checks are performed to check the robustness of the study results.

Table 9. Learning and Growth Factor Models

\begin{tabular}{|l|ll|ll|ll|ll|}
\hline Learning \& growth & Model 1 & & Model 2 & & Model 3 & & Model 4 & \\
\hline & Coef. & t-statistics & Coef. & t-statistics & Coef. & t-statistics & Coef. & t-statistics \\
\hline (Constant) & .107 & .361 & .248 & .834 & .080 & .272 & .220 & .736 \\
GOV\% & .113 & .572 & .059 & .292 & .160 & .805 & .090 & .449 \\
FOR \% & .008 & .054 & -.099 & -.714 & .025 & .173 & -.089 & -.642 \\
D_PRV\% & -1.444 & $-8.347^{* * *}$ & -1.499 & $-8.498^{* * *}$ & -1.429 & $-8.270^{* * *}$ & -1.482 & $-8.417^{* * *}$ \\
CON1 & -.217 & $-3.436^{* * *}$ & & & -.215 & $-3.439^{* * *}$ & & \\
MAJSH & & & -.182 & $-2.120^{* *}$ & & & -1.996 & $-1.996^{* *}$ \\
CAPADQ & .004 & $2.008^{* *}$ & .005 & $2.617^{* * *}$ & .004 & $2.274^{* *}$ & 2.844 & $2.844^{* * *}$ \\
Size & .150 & $5.533^{* * *}$ & .157 & $5.762^{* * *}$ & .148 & $5.557^{* * *}$ & 5.831 & $5.831^{* * *}$ \\
LIQ1 & .000 & -.523 & .000 & -.521 & & & & \\
LIQ2 & & & & & -.001 & $-1.587^{*}$ & -1.409 & $-1.409^{*}$ \\
INF & -.011 & $-2.095^{* *}$ & -.013 & $-2.488^{* * *}$ & -.011 & $-2.084^{* *}$ & -2.497 & $-2.497^{* * *}$ \\
GDP & .011 & $1.809^{* *}$ & .010 & $1.751^{* *}$ & .011 & $1.785^{* *}$ & 1.736 & $1.736^{* *}$ \\
\hline F-statistics & 14.524 & & 13.820 & & 14.744 & & 13.986 & \\
p-value for F- test & .000 & & .000 & & .000 & & 0.000 & \\
R-squared & .215 & & .207 & & .218 & & .209 & \\
Adjusted R2 & .200 & & .192 & & .203 & & .194 & \\
Mean VIF & 1.3 & & 1.28 & & 1.28 & & 1.26 & \\
\hline
\end{tabular}

Notes: $* * *$ Statistically significant at $1 \%, * *$ statistically significant at $5 \%$, *statistically significant at $10 \%$

In Table 9, the four models are highly significant with $p$-value $=.000$. The average inflation VIF of the models is lower than 10 indicating no multicollinearity problem exists. The regression results show that domestic private ownership has negative effect on the learning and growth factor. The result is statistically significant at $1 \%$ in the four models. Accordingly, domestic private banks should use modern technologies and new advanced techniques to enhance the workplace. Also, it is important to invest more in their stuff through offering training courses and workshops in order to improve their knowledge, skills and productivity. Ownership concentration also shows negative relationship with the learning and growth perspective. In model 1 and 3, ownership concentration measure CON1 has statistically significant negative effect learning and growth perspective. The result is statistically significant at 1\%. In model 2 and 4, ownership concentration measure MAJSH has significant negative effect on the learning and growth perspective. The result is statistically significant at $5 \%$. This negative effect can be justified by the expropriation hypothesis which comes at the 
cost of improving the workplace and investing in their stuff. The results is consistent with (Gutiérrez \& Tribo,2004; Boyd et al., 1998; Filatotchev et al.,2001;Alimehmeti and Paletta, 2012; Pinto and Augusto, 2014; Lee, 2008; Su and He, 2012) and contradicts with (Jensen and Meckling,1976; Shleifer and Vishny,1986; Affes and Hakim,2013; Heugenset al., 2009, Son et al., 2015).

With respect to the control variables, the results reveal that there is a negative association between inflation rate and the learning and growth perspective. The result is statistically significant at $1 \%$ in model 2 and 4 while it is significant at $5 \%$ in model 1 and 3 . When inflation increases, organizations find it costly to replace the old IT systems or to acquire new technologies. Moreover, offering new training courses or workshops for the employees will be at high cost.

GDP growth shows positive effect on the leaning and growth perspective. The result is statistically significant at $5 \%$ in the four models. During the period of high GDP growth, organizations recognizes the importance of enhancing their workplace, adapting new technologies and improving their staff skills in order to cope with the increased activity levels and to exploit the upward economic potentials. Liquidity is negatively correlated with the learning and growth factor. The result is statistically significant at $10 \%$ in model 3 and 4 . High liquidity ratios affect the bank ability to invest in their staff, offer workshops and training programs, update their IT systems and adopt new techniques. The negative association between bank liquidity and performance is consistent with the result reported (Molyneux and Thornton, 1992; Bordeleau and Graham, 2010; Holmström and Tirole, 1998).

Capital adequacy is positively associated with the learning and growth factor. The result is statistically significant at $1 \%$ in model 2 and 4 and highly significant at $1 \%$ in model 1 and 3 . Capital adequacy is a crucial determinant of bank safety and soundness. Therefore, maintaining adequate capital ratio positively affects the bank long term financial position which consequently affects its future potential growth (Uremadu, 2000; and Furlong \&Keeley, 1989). 


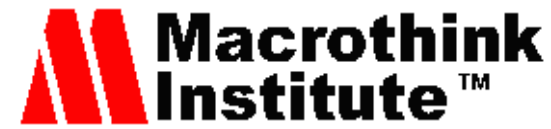

Table 10. Internal Process Factor Models

\begin{tabular}{|l|ll|lll|ll|ll|}
\hline Internal Process & Model 1 & & \multicolumn{2}{l}{ Model 2 } & & Model 3 & \multicolumn{2}{l|}{ Model 4 } \\
\hline & Coef. & t-statistics & Coef. & t-statistics & Coef. & t-statistics & Coef. & t-statistics \\
\hline GOV\% & -.199 & $-7.872^{* * *}$ & -.174 & $-6.705^{* * *}$ & -.187 & $-7.381^{* * *}$ & -.163 & $-6.282^{* * *}$ \\
FOR \% & -.006 & -.240 & .032 & $1.284^{*}$ & .000 & .006 & .038 & $1.538^{*}$ \\
D_PRV\% & .002 & .085 & .004 & .177 & .007 & .286 & .011 & .478 \\
CON1 & .135 & $4.705^{* * *}$ & & & .140 & $4.943^{* * *}$ & & \\
MAJSH & & & .026 & .919 & & & .040 & $1.419^{*}$ \\
CAPADQ & .144 & $5.474^{* * *}$ & .119 & $4.565^{* * *}$ & .160 & $6.149^{* * *}$ & .137 & 5.287 \\
Size & .829 & $31.306^{* * *}$ & .813 & $30.334^{* * *}$ & .819 & $31.476^{* * *}$ & .802 & 30.429 \\
LIQ1 & .025 & .949 & .036 & $1.323^{*}$ & & & & \\
LIQ2 & & & & & -.036 & $-1.403^{*}$ & -.035 & $-1.328^{*}$ \\
INF & .002 & .079 & .027 & .980 & -.001 & -.041 & .021 & .792 \\
GDP & -.016 & -.613 & -.015 & -.581 & -.019 & -.731 & -.019 & -.706 \\
\hline F-statistics & 93.469 & & 89.083 & & 93.696 & & 89.086 & \\
p-value for F- test & .000 & & .000 & & .000 & & 0.001 & \\
R-squared & .638 & & .627 & & .639 & & .627 & \\
Adjusted R2 & .631 & & .620 & & .632 & & .620 & \\
Mean VIF & 1.3 & & 1.28 & & 1.27 & & 1.25 & \\
\hline
\end{tabular}

Notes: $* * *$ Statistically significant at $1 \%, * *$ statistically significant at $5 \%$, $*$ statistically significant at $10 \%$.

Table (10) shows that the models are highly significant with $p$-value $=0.000$. The average VIF of the model variables does not indicate multicollinearity problem. Government ownership has a negative effect on the internal process factor that is statistically significant at $1 \%$ in the four models. Referring to the social welfare theory and the political theory, governmentowned banks suffer from high nonperforming loan ratios, poor loan portfolio and high non interest expenditures which inversely affect the efficiency of their internal process. This is consistent with the findings of (Farazi et al., 2011; Boussaada and Karmani. 2015; Kobeissi and Sun, 2010; Bonin, Hasan and Wachtel, 2004). On the contrary, foreign ownership shows positive effect on the internal process factor. The result is statistically significant at $10 \%$ in model 2 and 4 which supports the global advantage hypothesis thatforeign banks have new advanced portfolio, risk management and strategic techniques which increase their internal process efficiency (Akhtar, 2010; and Berger et al., 2000).

Ownership concentration measure CON1 is positively related to the internal process factor in model 1 and 3 and the relation is statistically significant at 1\%. Likewise, Ownership concentration measure MAJSH has positive correlation with the internal factor in model 4 and the result is statistically significant at $10 \%$. The results support the monitoring hypothesis 
that ownership concentration leads to more efficient internal process and governance structure. This result is consistent with the results reported by (Jensen and Meckling, 1976; Shleifer and Vishny, 1986; Affes and Hakim, 2013; Son et al., 2015; Heugens et al., 2009).

Regarding the control variables, capital adequacy hasstatistically significant positive effect at $1 \%$ on the internal process factor in models 1,2 and 3. Well-capitalized banks has less bankruptcy risk and are more efficient in raising fund at lower cost which positively affects the internal process mechanisms (Berger et al,1995; Demirgüç-Kunt and Huizinga,2000). Bank size also shows positive association with bank internal process factor in model 1,2 and 3.The result is statistically significant at $1 \%$. Due to increasing economies of scale, banks with large size have the necessary resources to adequately monitor the internal operations and the work processes. The result confirms the findings of Kwan (2003) and Boussaada and Karmani, (2015). Liquidity shows contradictory results with respect to the internal process factor. In Model 2, the liquidity measure LIQ 1 is positively correlated with the internal process factor. The result is statistically significant at $10 \%$. Consistent with the results reported by (Bourke, 1989; Almazari, 2014; Anyanwu, 1993; Nwankwo, 1991), maintaining adequate liquidity level smoothes the bank operations during the period of financial distress and helps compensating the net cash outflow.

On the other side, the liquidity measure LIQ2 has a negative correlation with the internal process factor in model 3 and 4 . The result is statistically significant at $10 \%$ in model 3 and 4 . High liquidity ratio comes at the cost of using this fund in improving the business techniques and operations. The result is consistent with the findings reported by (Molyneux and Thornton, 1992; Bordeleau and Graham, 2010; Holmström and Tirole, 1998).

Capital adequacy shows significant positive effect on the internal process factor. The result is statistically significant at $1 \%$ in model 1,2 and 3. Consistent with the results reported (Molyneux and Thorton, 1992; Berger et al., 1995), Capital adequacy enables banks to absorb the financial shocks which ensures the soundness of the banking system and improves the internal operations of the banks. 
Table 11. Customer Factor Models

\begin{tabular}{|c|c|c|c|c|c|c|c|c|}
\hline Customer & Model & & Model & & Model & & Model & \\
\hline & Coef. & $\mathrm{t}$-statistics & Coef. & $\mathrm{t}$-statistics & Coef. & t-statistics & Coef. & t-statistics \\
\hline (Constant) & -1.169 & $-3.580^{* * *}$ & -1.025 & $-3.147^{* * *}$ & -1.173 & $-3.583^{* * *}$ & -1.039 & $-3.175^{* * *}$ \\
\hline GOV\% & .510 & $2.332^{* * *}$ & .626 & $2.851^{* * *}$ & .590 & $2.677^{* * *}$ & .690 & $3.120^{* * *}$ \\
\hline FOR \% & .312 & $1.960^{* *}$ & .338 & $2.221^{* *}$ & .345 & $2.163^{* *}$ & .369 & $2.421^{* * *}$ \\
\hline D_PRV\% & -.144 & -.755 & -.242 & -1.257 & -.111 & -.581 & -.197 & -1.020 \\
\hline CON1 & -.112 & $-1.609^{*}$ & & & -.097 & $-1.402^{*}$ & & \\
\hline MAJSH & & & -.297 & $-3.160^{* * *}$ & & & -.259 & $-2.766^{* * *}$ \\
\hline CAPADQ & -.001 & -.747 & -.001 & -.659 & .000 & -.201 & .000 & -.109 \\
\hline Size & .103 & $3.426^{* * *}$ & .098 & $3.281^{* * *}$ & .091 & $3.093^{* * *}$ & .086 & $2.921^{* * *}$ \\
\hline LIQ1 & .001 & $1.401^{*}$ & .001 & $1.819^{* *}$ & & & & \\
\hline LIQ2 & & & & & -.001 & -.628 & .000 & -.226 \\
\hline INF & -.005 & -.822 & -.003 & -.599 & -.006 & -.977 & -.004 & -.809 \\
\hline GDP & -.010 & $-1.539^{*}$ & -.011 & $-1.618^{*}$ & -.011 & $-1.654^{* *}$ & -.011 & $-1.731^{* *}$ \\
\hline F-statistics & 2.345 & & 2.937 & & 2.219 & & 2.674 & \\
\hline $\mathrm{p}$-value for $\mathrm{F}$ - test & .005 & & .000 & & .008 & & 0.001 & \\
\hline R-squared & .042 & & .053 & & .040 & & .048 & \\
\hline Adjusted R2 & .024 & & .035 & & .022 & & .030 & \\
\hline Mean VIF & 1.3 & & 1.28 & & 1.27 & & 1.25 & \\
\hline
\end{tabular}

Notes: *** Statistically significant at $1 \%, * *$ statistically significant at $5 \%$, *statistically significant at $10 \%$

Regarding the customer perspective, Table (11) shows that the regression models are highly significant with $\mathrm{p}$-value $=0.000$ and no multicollinearity problem exists as the averageVIF of the model variables are below 10. The findings reveal astatistically significant positive association between governmental ownership and the customer at $1 \%$ in the four models. This result is consistent with (Loukil and Chaabane, 2005; Sathye, 2003; Wanniarachchige, 2011). Governmental banks have superior advantage in attracting customer deposits at lower costs compared to the private counterparts, accordingly they have more credits transactions, investments and projects in different regions that are not reachable by their counterparts.

Similarly, foreign ownership has positive effect on the customer factor. The result is statistically significant at $1 \%$ in model 4 and significant at $5 \%$ in model 1,2 and 3 . The result confirms the global advantage hypothesis and consistent with (Al-Amarneh, 2014; Boussaada and Karmani, 2015; Arouri, Hossain and Muttakin, 2011; Akhtar, 2010). Foreign banks have innovative deposit insurance and financial services which positively affect their relationship with the clients. Moreover, Customers perceive foreign banks as safe haven during domestic 
financial crisis (Peek and Rosengren, 2000; Hull 2002).

Ownership concentration is negatively related to the customer factor in the four models. The concentration measure CON1 has statistically significant negative relationship to the customer factor in model 1 and 3 at $10 \%$ and the concentration measure MAJSH has a statistically significant negative relationship with the customer factor at $1 \%$ in model 2 and 4 . Referring to the expropriation effect, Highly concentrated ownership negatively affects the customers' perception of the bank, the investment opportunities and the customer service offered by the bank (Johnson et al., 2000; Gutiérrez and Tribo, 2004; Boyd et al., 1998; Filatotchev et al., 2001). Bank size is positively correlated to the customer factor in the four models. The result is statistically significant at $1 \%$. Assuming increasing return to scale, bank size is associated with higher bank profitability which positively affects the bank reputation, rank and the customer perception of the bank (Sudin: 1996, Valentina et al., 2009).

Liquidity has positive effect on the customer factor. The result is statistically significant at $10 \%$ in model 1 and significant at 5\% in model 2 . Liquidity is crucial determinant of bank performance specifically the customer factor. The positive effect of liquidity on the customer factor is consistent with the previous results of (Anyanwu, 1993; Spindt, 1980) who report that bank liquidity is critical to maintain the customers' confidence. The GDP growth shows statistically significant negative effect on the customer factor in the four models. High GDP growth increases the customer marginal propensity to consume which negatively influences the customer factor measured by the deposit market share (Blanchard et al., 2013; Krugman and Wells, 2013; Parkin, 2014). 


\section{Macrothink}

Table 12. Financial Factor Models

\begin{tabular}{|c|c|c|c|c|c|c|c|c|}
\hline \multirow[t]{2}{*}{ Financial } & \multicolumn{2}{|c|}{ Model 1} & \multicolumn{2}{|c|}{ Model 2} & \multicolumn{2}{|c|}{ Model 3} & \multicolumn{2}{|c|}{ Model 4} \\
\hline & Coef. & t-statistics & Coef. & t-statistics & Coef & t-statistics & Coef & t-statistics \\
\hline (Constant) & -.237 & -.724 & -.219 & -.667 & -.240 & -.730 & -.227 & -.688 \\
\hline GOV\% & -.563 & $-2.566^{* * *}$ & -.512 & $-2.313^{* *}$ & -.531 & $-2.406^{* * *}$ & -.486 & $-2.185^{* *}$ \\
\hline FOR \% & .428 & $2.682^{* * *}$ & .459 & $2.994^{* * *}$ & .441 & $2.760^{* * *}$ & .472 & $3.078^{* * *}$ \\
\hline D_PRV\% & .104 & .544 & .083 & .429 & .117 & .611 & .102 & .523 \\
\hline CON1 & .008 & .121 & & & .014 & .203 & & \\
\hline MAJSH & & & -.060 & -.634 & & & -.045 & -.477 \\
\hline CAPADQ & .001 & .548 & .001 & .484 & .001 & .766 & .001 & .707 \\
\hline Size & .030 & .991 & .027 & .891 & .026 & .862 & .022 & .752 \\
\hline LIQ1 & .000 & .502 & .000 & .638 & & & & \\
\hline LIQ2 & & & & & .000 & -.284 & .000 & -.186 \\
\hline INF & .005 & .816 & .005 & .974 & .004 & .764 & .005 & .902 \\
\hline GDP & -.003 & -.399 & -.003 & -.414 & -.003 & -.443 & -.003 & -.458 \\
\hline F-statistics & 1.962 & & 1.993 & & 1.949 & & 1.963 & \\
\hline $\mathrm{p}$-value for $\mathrm{F}$ - test & .021 & & .019 & & .023 & & .021 & \\
\hline R-squared & .036 & & .036 & & .035 & & .036 & \\
\hline Adjusted R2 & .018 & & .018 & & .017 & & .018 & \\
\hline Mean VIF & 1.3 & & 1.28 & & 1.275 & & 1.258 & \\
\hline
\end{tabular}

Notes: $* * *$ Statistically significant at $1 \%, * *$ statistically significant at $5 \%$, *statistically significant at $10 \%$

With respect to the financial perspective, the regression results show that there is a negative relationship between governmental ownership and the financial performance of the bank and the result is statistically significant at $1 \%$ in model 1 and 3 and statistically significant at $5 \%$ in model 2 and 4 . The poor financial performance of the governmental banks is supported by the social welfare theory and the political theory. (Bonin, Hasan and Wachtel, 2004; Micco, Panizzaand Yañez, 2004; Fungacova et al., 2013; Bertay et al., 2015; Shleifer and Vishny 1994; Shleifer, 1998; Sapienza, 2004; Micco and Panniza, 2006; Dinç, 2005).

Foreign ownership has a statistically significant positive effect on the financial performance at $1 \%$ in the four models. This result supports the global advantage hypothesis and is consistent with the previous studies by (Al-Amarneh, 2014; Boussaada and Karmani, 2015; Arouri, Hossain and Muttakin, 2011; Akhtar, 2010). On the other side, Domestic private ownership and ownership concentration do not show statistically significant effect on the financial factor in the four models. 


\section{Conclusion}

This study investigates the effect of ownership structure on bank performance in the MENA region by applying the balanced scorecard method using a panel of 137 commercial banks during the period from 2010 to 2014 across twelve countries in the MENA region. The regression results reveal a statistically significant positive association between foreign ownership and BSC index while domestic private ownership shows a statistically significant negative effect on the BSC index. In contrary with the social welfare theory and the political theory, government ownership has a statistically significant positive effect on the BSC index (Loukil and Chaabane, 2005; Sathye, 2003; Wanniarachchige, 2011).

Consistent with the expropriation hypothesis, Ownership concentration has a statistically significant negative effect on the BSC index. With respect to the control variables, the regression results convey that there is statistically significant positive correlation between bank size and BSC index due to increasing return to scale whereas inflation has a negative effect on the BSC index that is statistically significant at $10 \%$. Analyzing the impact of the ownership structure on each of the four perspective of the balanced scorecard, additional regression analyses are run. Government ownership has statistically negative impact on the banks' financial performance. This result is consistent with the social welfare theory and the political theory. On the contrary, ownership concentration and domestic private ownership does not show statistically significant effect on bank's financial performance. Regarding the learning and growth factor, the results convey that domestic private ownership has a statistically significant negative impact on the learning and growth factor. Similarly, ownership concentration, inflation and liquidity are negatively correlated with the learning and growth factor. On the hand, bank size, capital adequacy and the GDP growth show a statistically significant positive impact on this factor.

Concerning the customer perspective, the findings reveal that there is a positive association between government ownership and the customer factor as customer perceive state owned banks as safe banks. Consistent with global advantage hypothesis, foreign ownership also shows statistically significant positive effect on the customer. Ownership concentration and GDP growth have a statistically significant negative effect on the customer factor while bank size and liquidity are positively correlated with the customer factor.

With respect to the internal process perspective, Government ownership has a negative effect on the internal process factor in confirmatory with the social welfare theory and the political theory while foreign ownership is positively correlated with the internal process factor which is consistent with the global advantage hypothesis.. Similarly, ownership concentration shows statistically significant positive effect on the internal process factor due to the monitoring effect. Bank size and capital adequacy show statistically significant effect on the internal process factor while liquidity shows contradictory results with respect to the internal process factor.

\section{References}

Affes,H., \& Hakim, N. H. (2013). Ownership Structure and Performance of the Listed 
Tunisian Companies.Business and Economic Research. Macrothink institute, 3(2), 218-235. https://doi.org/10.5296/ber.v3i2.4332

Akhtar, M. H. (2010). X-Efficiency analysis of Pakistani commercial banks. International Management Review, 6(1), 12.

Al-Amarneh, A. (2014). Corporate governance, ownership structure and bank performance in Jordan. International Journal of Economics and Finance, 6(6), 192-202. https://doi.org/10.5539/ijef.v6n6p192

Alimehmeti, G., \& Paletta, A. (2012). Ownership concentration and effects over firm performance: Evidences from Italy. European Scientific Journal, 8(22).

Almazari, A. A. (2014). Impact of Internal Factors on Bank Profitability: Comparative Study between Saudi Arabia and Jordan. Journal of Applied Finance \& Banking, 4(1), 125-140. [Online] Available: http://www.scienpress.com

Al-Najjar, S. M., \& Kalaf, K. H. (2012). Designing a balanced scorecard to measure a bank's performance: A case study. International journal of business administration, 3(4), 44-53. https://doi.org/10.5430/ijba.v3n4p44

Altunbas, Y., Liu, M.H. Molyneux, P., \& Seth, R. (2000). Efficiency and Risk in Japanese Banking. Journal of Banking and Finance, 24(10), 1605-1628. https://doi.org/10.1016/S0378-4266(99)00095-3

Anyanwu, J. C. (1993). Monetary Economics: Theory, Policy and Institutions. Benin City. Hybrid Professional Publishers Ltd, application (WISA), Nanchang, China, 206-209.

Arif,M., Khan, M. Z., \& Iqbal, M. (2013). Impact of Bank size on Profitability: Evidence from Pakistan. International Journal of Applied Research, 2, 98-109

Arouri, H., Hossain, M., \&Muttakin, M. B. (2011). Ownership structure, corporate governance and bank performance: evidence from GCC countries. Corporate Ownership and Control, 8(4), 365-372. https://doi.org/10.22495/cocv8i4c3art5

Athanasoglou, P.P., Brissimis, S.N., \& Delis, M.D. (2008).Bank-specific, industry-specific and macroeconomic determinants of bank profitability. Journal of International Financial Markets Institutions Money, 18(2), 121-136. http://dx.doi.org/10.1016/j.intfin.2006.07.001

Atkinson, H. (2006). Strategy implementation: a role for the balanced scorecard?.Management Decision, $\quad 44(10), \quad 1441-1460$. https://doi.org/10.1108/00251740610715740

Aymen, B. M. M. (2014). Impact of Ownership Structure on Financial Performance of Banks: Case of Tunisia. Journal of Applied Finance and Banking, 4(2), 163-182

Barth, J. R., Gan, J., \& Nolle, D.E. (2004). Global Banking Regulation \& Supervision: What Are the Issues and What Are the Practices, In: Focus on Financial Institutions and Services, Nova Science 
Berger, A. N., DeYoung, R., Genay, H., \& Udell, G. F. (2000). Globalization of financial institutions: Evidence from cross-border banking performance. Brookings-Wharton papers on financial services, 1, 23-120. https://doi.org/10.1353/pfs.2000.0001

Berger, A.N., Herring, R.J., \&Szego, G.P. (1995).The role of capital in financial institutions. Journal of Banking and Finance, 19, 257-276. https://doi.org/10.1016/0378-4266(95)00002-X

Bertay, A. C., Demirgüç-Kunt, A., \& Huizinga, H. (2015). Bank ownership and credit over the business cycle: Is lending by state banks less procyclical? Journal of Banking \& Finance, 50, 326-339. https://doi.org/10.1016/j.jbankfin.2014.03.012

Blanchard, O., Giavazzi, F., \& Amighini, A. (2013). Macroeconomics: A European Perspective, Harlow: Pearson, ISBN: 978-0-273-77168-5.

Bonin, J. P., Hasan, I., \& Wachtel, P. (2005). Bank performance, efficiency and ownership in transition countries.Journal of banking \& finance, 29(1), 31-53. https://doi.org/10.1016/j.jbankfin.2004.06.015

Bordeleau, É., \& Graham, C. (2010). The impact of liquidity on bank profitability (Bank of Canada Working Paper. Working paper No. 2010, 38.

Boussaada, R., \& Karmani, M. (2015). Ownership Concentration and Bank Performance: Evidence from MENA Banks. International Journal of Business and Management, 10(3), 189-202. https://doi.org/10.5539/ijbm.v10n3p189

Boyd, J. H., Chang, C., \& Smith, B. D. (1998).Moral hazard under commercial and universal banking. Journal of Money, Credit and Banking, 30, 426-468. https://doi.org/10.2307/2601249

Cetorelli,N., Goldberg, L.S. (2009). Globalized Banks: Lending to Emerging Markets in the Crisis. In: Federal Reserve Bank of New York Staff Reports. Staff Report no. 377. https://doi.org/10.2139/ssrn.1432498

Claessens, S, D. S. \& Lang, L.H.P. (2000). The Separation of Ownership and Control in East Asian Corporations. Journal of Financial Economics, 58, 81-112.

Clarke, G., Cull, R., Peria, M.S.M, \& Sánchez, S.M. (2003). Foreign Bank Entry: Experience, Implications for Developing

Demirgüç-Kunt, A., \& Huizinga, H. (1999). Determinants of commercial bank interest margins and profitability: some international evidence. The World Bank Economic Review, 13(2), 379-408. https://doi.org/10.1093/wber/13.2.379

Demsetz, H. (1983). The structure of ownership and the theory of the firm. Journal of Law and Economic, 26(2), 357-390. https://doi.org/10.1086/467041

Dermine, J. (2002). European Banking, Past, Present and Future. Presentation at the Second ECB Central Banking Conference, Frankfurt, pp 1-101. 
Dinc, S. (2005). Politicians and banks: political influences on government-owned banks in emerging countries. Journal of Financial Economics, 77, 453-479. https://doi.org/10.1016/j.jfineco.2004.06.011

ElBannan, M. A., \& ElBannan, M. A. (2014). Corporate Governance and Accounting Performance: A Balanced Scorecard Approach. Accounting and Finance Research, 3(2), 60-76. https://doi.org/10.5430/afr.v3n2p60

Farazi, S., Feyen, E., \& Rocha, R. (2011). Bank Ownership and Performance in the Middle East and North Africa Region.

Filatotchev, I., Kapelyushnikov, R., Dyomina, N., \& Aukutsionek, S. (2001). The effects of ownership concentration on investment and performance in privatized firms in Russia. Managerial and Decision Economics, 22(6), 299-313. https://doi.org/10.1002/mde.1008

Furlong, F. T., \& Keeley, M. C. (1989). Capital regulation and bank risk-taking: A note. Journal of banking \& finance, 13(6), 883-891. https://doi.org/10.1016/0378-4266(89)90008-3

Girardone, C., Molyneux, P., \& Gardener, E.P. (2004).Analysing the Determinants of Bank Efficiency: The Case of Italian Banks. Applied Economics, 36(3), 215-227. https://doi.org/10.1080/0003684042000175334

Goddard, J., Molyneux, P., \& Wilson, J. (2004). The profitability of European banks: A cross-sectional and dynamic panel analysis. The Manchester School, 72(3), 363-381. https://doi.org/10.1111/j.1467-9957.2004.00397.x

Goldberg, L.S. (2007). The International Exposure of U.S. Banks Europe and Latin America Compared. In: the National Bureau of Economic Research, 203-236.

Gutiérrez, M., \&Tribó, J. A. (2004). Private Benefits Extraction in Closely-held Corporations: The Case for Multiple Large Shareholders. Working Paper, European Corporate Governance Institute.

Heugens, P. R., van Essen, M., \& van Oosterhout, J. (2009). Meta-analyzing ownership concentration and firm performance in Asia: Towards a more fine-grained understanding. Asia Pacific Journal of Management, 26(3), 481-512. https://doi.org/10.1007/s10490-008-9109-0

Holmström, B., \& Tirole.J. (1998). Private and public supply of liquidity, Journal of Political Economy, 106, 1-40. https://doi.org/10.1086/250001

Hovey, M., Li, L., \& Naughton, T. (2003).The relationship between valuation and ownership of listed firms in China. Corporate Governance: An International Review, 11(2), 112-122. https://doi.org/10.1111/1467-8683.00012

Hughes, J.P., \& Mester, L.J. (1993). A Quality and Risk-adjusted Cost Function for Banks: Evidence on the 'Too-Big-to-Fail' Doctrine. Journal of Productivity Analysis, 4(3), 293-315. https://doi.org/10.1007/BF01073414

Ibrahim, M., \& Murtala, S. (2015). The relevance of the balanced scorecard as a technique for 
assessing performance in the Nigerian banking industry. European Journal of Business, Economics and Accountancy, 3(4), 71-80

Isoraite, M. (2007). The balanced scorecard method as a tool evaluating performance of local authority. Ekonomikairvadyba, 2(9), 76-82

Jensen, M. C., \&Meckling, W. H. (1976). Theory of the firm: Managerial behavior, agency costs and ownership structure. Journal of financial economics, 3(4), 305-360. https://doi.org/10.1016/0304-405X(76)90026-X

Johnson, S., La Porta, R., Lopez de Silanes, F., \& Shleifer, A. (2000). Tunneling. American Economic Review, 90, 22-27. https://doi.org/10.1257/aer.90.2.22

Kaplan, R. S., \& Norton, D. P. (2002). Strategy maps. Converting Intangible Assets into Tangible Outcomes. Harvard Business Review.

Kaplan, R. S., \& Norton, D. P. (1997). Balanced Scorecard: Strategienerfolgreichumsetzen, ausdemAmerikanischen von Horváth, P., Stuttgart.

Karim, M.Z.A., Chan, S.G., \& Hassan, S. (2010). Bank efficiency and non-performing loans: evidence from Malaysia and Singapore. Prague Economic Papers, 19(2), 118-132. https://doi.org/10.18267/j.pep.367

Kiuri, R. M. (2013). The effects of ownership structure on bank profitability in Kenya. European Journal of Management Sciences and Economics, 1(2), 116-127.

Kobeissi, N., \& Sun, X. (2010). Ownership structure and bank performance: Evidence from the Middle East and North Africa Region. Comparative Economic Studies, 52(3), 287-323. https://doi.org/10.1057/ces.2010.10

Krugman, P., \& Wells, R. (2013). Economics, 3rd edition, Macmillan, ISBN: 1-4292-5163-8

Laeven, L.A., \& Levine, R. (2009). Bank governance, regulation and risk taking. Journal of Financial Economics, 93, 259-275. https://doi.org/10.1016/j.jfineco.2008.09.003

Lee, S. (2008). Ownership structure and financial performance: Evidence from panel data of South Korea. Corporate ownership and Control, 6(2), 1-25. https://doi.org/10.22495/cocv6i2c2p1

Lensink, R., \&Naaborg, I. (2007). Does foreign ownership foster bank performance?.Applied Financial Economics, 17(11), 881-885. https://doi.org/10.1080/09603100600827653

Levine, R. (1996). Foreign Banks, Financial Developments and Economic Growth. International Financial Markets: Harmonization versus Competition, the AEI Press: Washington. https://doi.org/10.1016/j.econlet.2006.05.009

Loukil. K. A. Chaabane. (2005). Structure de propriété et performance financière: cas des banques de dépôt en Tunisie. HAL Post-Print

Micco, A., \&Panizza, U. (2006).Bank ownership and lending behavior. Economics Letters, 93(2), 248-254. https://doi.org/10.2139/ssrn.1818718 
Micco, A., Panizza, U., \& Yañez, M. (2004). Bank ownership and performance. In: Inter-American Development Bank Working paper series, working paper no. 518

Molyneux, P., \& Thornton, J. (1992). Determinants of European bank profitability: a note. Journal of Banking \& Finance, 16(6), 1173-1178. https://doi.org/10.1016/0378-4266(92)90065-8

Naceur, S. B., \& Kandil, M. (2009). The impact of capital requirements on banks' cost of intermediation and performance: The case of Egypt. Journal of Economics and Business, 61(1), 70-89. https://doi.org/10.1016/j.jeconbus.2007.12.001

Nwankwo, G.O. (1991). Bank Management, Principles and Practice, Malthouse Press Ltd. Lagos.

Ombuna, D. S., Omido, K., Garashi, H. M., Odera, O., \& Okaka, O. (2013). Impact of balanced scorecard usage on the performance of commercial banks. International Journal of Information Technology and Business Management, 10(1), 40-48.

Parkin, M. (2014). Economics, eleventh edition, Pearson, ISBN: 0273789961

Peek, J. and Rosengren, S.E.(2000), Implications of the Globalization of the Banking Sector: The Latin American Experience. Federal Reserve Bank of Boston New England Economic Review, 45-62.

Perry, P. (1992). Do banks gain or lose from inflation? Journal of Retail Banking, 14(2), 25-30

Pinto, A. P. S., \& Augusto, M. G. (2014). Are there non-linear relationships between ownership structure and operational performance? Empirical evidence from portuguese SMEs using dynamic panel data. International Journal of Business Administration, 5(3), 162-180.

Rose, P. S., \& Hudgins, S.C. (2008). Bank Management and financial services. MCGRAW-Hill/Irwin, $7^{\text {th }}$ edition, Boston

Sapienza, P. (2002). What do state-owned firms maximize? Evidence from Italian banks. https://doi.org/10.2139/ssrn.303381

Sathye, M. (2003). Efficiency of banks in a developing economy: The case of India. European Journal of Operational Research, 148(3), 662-671. https://doi.org/10.1016/S0377-2217(02)00471-X

Shleifer, A. (1998). State versus private ownership .National bureau of economic research. working paper No. w6665. https://doi.org/10.3386/w6665

Shleifer, A., \& Vishny, R. W. (1986). Large shareholders and corporate control.Journal of Political Economy, 94, 461-489. https://doi.org/10.1086/261385

Shleifer, A., \& Vishny, R.W. (1994). Politicians and firms. Quarterly Journal of Economics, 109, 995-1025. https://doi.org/10.2307/2118354 
Son, N. H., Tu, T. T. T., Cuong, D. X., Ngoc, L. A., \& Khanh, P. B. (2015). Impact of Ownership Structure and Bank Performance-An Empirical Test in Vietnamese Banks. International Journal of Financial Research, 6(4), 123-133. https://doi.org/10.5430/ijfr.v6n4p123

Spindt P A and V Tarhan (1980). Liquidity structure adjustment behavior of large money center banks. Journal of Money, Credit and Banking. Ohio State University Press. https://doi.org/10.2307/1991772

Su, D., \& He, X. (2012).Ownership structure, corporate governance and productive efficiency in China. Journal of productivity analysis, 38(3), 303-318. https://doi.org/10.2307/1991772

SudinHaron. (1996). Competition and other external determinants of the profitability of Islamic banks. Islamic economic studies, 4, 50-65.

Tominac, S. B. (2014). Possibilities of Balanced Scorecard Application in Commercial Banks.Economics, 3, No.10.

Umar, M., Maijama'a, D., \& Adamu, M. (2014). Conceptual exposition of the effect of inflation on bank performance.Journal of World Economic Research, 3(5), 55-59. https://doi.org/10.11648/j.jwer.20140305.11

Uremadu, S.O. (2000). Bank Management: Basic Issues in Money, Bank Lending and Credit Administration, Mindex Publishing Company Benin.

Vagizova, V., \& Klaas, J. (2014). Formation of sustainable development strategy of credit organizations based on balanced scorecard. Investment Management and financial innovations, 11(1), 87-96.

ValentinaFlamini Calvin McDonald, \& Liliana Schumacher. (2009). The determinants of commercial bank profitability in Sub-Saharan Africa. IMF working Paper 09/15, 2-32.

Wang, W. (2005). An evaluation of the Balanced Scorecard in equity valuation: The case of exchange ratio in the Mergers and acquisitions of Taiwan's financial industry. Journal of Intellectual Capital, 6(2), 206-221. https://doi.org/10.1108/14691930510592807

Wanniarachchige, M. K. (2011). How does ownership affect Bank performance. The case of Indian Commercial Banks. The International Business and Economics Research Journal, 10(3), 71-81. https://doi.org/10.19030/iber.v10i3.4103

Zouari,S. B., Taktak, N.B. (2014). Ownership structure and financial performance in Islamic banks: Does bank ownership matter?. International Journal of Islamic and Middle Eastern Finance and Management, 7(2), 146-160. https://doi.org/10.1108/IMEFM-01-2013-0002 